\title{
Perception of the health of children living and working on the streets of Sunnyside Part 2: Methodology, interpretation and recommendations
}

\author{
L Prinsloo, M Cur, Department of Nursing Science, University of Pretoria \\ MS Richter, D Cur, Faculty of Nursing, University of Alberta* \\ *(Note during course of the study: Lecturer: Department of Nursing Science, \\ University of Pretoria)
}

\section{Introduction}

In part one of the article, a thorough literature review was done on the phenomenon of street children. Part two of the article will cover the methodology, interpretation and recommendations.

\section{Background to the problem}

The number of street children has grown because of the current economic hardship in South Africa, increasing levels of violence, and widespread family and community disruption. Despite a lack of precise information, indicators show that the number of genuine street children in South Africa is substantial and growing (Donald \& Swart-Kruger 1994: 170).

Given the extent of the problem, the health of these children is a serious concern. Does a life on the streets affect their health negatively and, if so, how? Answers to these questions are essential, to determine the focus, and form, of preventative and direct intervention programmes.

The major risks and sources of vulnerability, to which street children may be exposed, relate to shelter, safety and nutrition. Specific health risks associated with untreated illnesses and injuries, glue sniffing and sexual activities, are also threatening to them. In particular, street children are in danger from:

- $\quad$ physical exposure to cold and damp, due to lack of shelter and insufficient protective clothing;

- $\quad$ pedestrian traffic accidents, particularly (but not only) following glue sniffing (Swart 1990: 5); and

- $\quad$ exposure to violence and physical abuse by gangs, criminal elements, adult street dwellers and police (Gebers 1990: 14; Cockburn 1991: 4).

Nutritional needs are unreliably and insufficiently met. There is a high risk of contracting sexually transmitted diseases, AIDS being of special concern (Swart 1990: 8).
Street children keep most illnesses and injuries to themselves. Group members are frequently the only source of support and care, during such crises (Gebers 1990: 13; Richter 1990: 96; Swart 1990: 5). In terms of health, it is clear that street children may be vulnerable to a range of severe risks. Some (although not all) of these risks, are contained through coping strategies and adaptations, which the street children have developed to survive. It is significant that, on a physical level, these strategies are felt to yield a better life, than the life in a closed childcare institution (Richter 1991: 7). It is also clear that the real risks to health are long-term, and that, while the children's adaptations might be effective as short-term coping strategies, the long-term risks remain.

The situation in Sunnyside is no different from that found in the literature. During the past decade, Sunnyside has experienced a population explosion, caused by the urbanization of thousands of people because of economic necessity. Sunnyside is a community within the Metropolitan Area of Tswane. Urbanization is the cause of many social and health problems, due to poor living conditions and a consequent lowering in living standards. There is a high rate of unemployment due to overpopulation. Proposed solutions to these problems are: the involvement of the community in identifying problems and finding possible solutions; an efficient primary health care service; the creation of a better, healthier environment, with the infrastructure necessary to maintain it (Van Rensburg 1994: 134).

Most of the children are normal children with individual strengths and weaknesses. They try to survive, but they need a helping hand. It is necessary to give attention to the following risks: drugs, alcohol, sexual behavior, prostitution, sexually transmitted infections (STIs), HIV/AIDS, glue sniffing, personal hygiene and nutrition. Health promotion can make the street child aware of the risks they run, and the life they lead (Fieldwork 2000).

\section{Problem statement}

The street child's view of health may differ considerably 
from that of the researcher. The researcher first has to internalize the street child's ideas, beliefs and values about health, before health promotion and healthy practices can be planned.

What effect does this view of health and health promotion have on the role of the community health worker as health promoter? Community health workers may assume their perceptions and assessments of a client's health status as accurate and congruent with those of the client. However, discrepancies exist between the perceptions of clients, in this case the street children, and those of community health workers. This can have serious consequences when planning health promotion strategies (Jenkins \& Emmet 1997: 427).

\section{Purpose of the study}

The purpose of the study was to describe the perceptions of street children concerning their own health.

\section{Objectives of the study}

The objectives of this study are:

- $\quad$ to describe the street children's perspectives on health,

- $\quad$ to describe suggestions concerning health promotion strategies when working with street children.

\section{The theoretical framework}

This study is based on the theoretical framework of Neuman's theory, for teaching a holistic approach to client problems. The Neuman theory presents a comprehensive and systematic approach for organizing nursing phenomena. It is a valuable theory for structuring relationships between clients (street children), client systems and the researcher. The theory is an attempt to provide a framework for viewing health care problems. The Neuman theory focuses primarily on two concepts: the nature of an individual's, or group's, response to stress factors, and the community health worker's activities to assist the person to best respond to these stress factors. The theory represents important aspects of general and specific types of health care, while being comprehensive in relation to nursing care approaches. The ultimate goal of primary prevention is implicit in the theory. The theory generates new approaches to street children's concerns and its usefulness is validated in this research.

The Neuman theory provides the opportunity for community health nurses to draw on related scientific knowledge, and use it in a more appropriate way for health promotion. There are four metaparadigm concepts included in the theory: person, environment, health and nursing.

Neuman states that:

- $\quad$ Nursing is concerned with the total person and is a 'unique' profession concerned with all variables affecting a client's response to stress factors. In this case, nursing will be health promotion strate gies and health care access to the street children in their environment, the streets of Sunnyside.

- A person is at all times in some state of health or illness and is a dynamic composite of interrelationships between physiological, psychological, sociocultural, developmental and spiritual factors. In this case, the person will be the street child. The street child is mostly on the neutral point of the illness/ wellness continuum, only realizing that something is wrong with his body when disability in the interrelationships occurs, that cannot be solved by his protective factors.

- Internal and external environments exist for the client, and varying degrees of harmony and balance between the internal and external environments are maintained. In this case, the street children have no external environment. The street children have to use their unique protective factors, such as creativity, to keep the balance and harmony in their health, to survive.

- Health is the condition in which parts and subparts of the whole person are in harmony. In this case, the street children have no harmony on the streets, and their health is affected by it, even if they do not always realize it.

\section{Research design}

A qualitative descriptive design was followed in this study.

\section{Population and sampling}

The population consists of all the children living and working on the street of Sunnyside. Purposive sampling was used. This type of sampling is based on the judgment of the researcher (De Vos 1998: 198). The researcher worked with the street children for 18 months prior to the study. She knew the participants and they knew her. The researcher purposively chose nine participants out of the group visiting a gathering place, the Koffie Huis, to participate in the research. Participants were all black boys, aged $9-13$ years, living and working on the streets of Sunnyside. They were chosen because they shared similar backgrounds.

\section{Methods used to obtain data}

Focus group interviews and field notes were used as data gathering method. The unstructured interview technique was used. It promoted open communication, allowed the participants to comment, ask questions, and to respond to comments on the topic of their perception of health. Guided by a skilled interviewer, the participants shared their ideas and perceptions and influenced each other to respond to ideas and comments in the discussions. The researcher acted as fieldworker.

The field notes included observational, theoretical and methodological notes. Four focus groups were conducted, with the same group of participants. Data was gathered until saturation of data was reached. The data was transcribed within 72 hours, after each meeting. 


\section{Data analysis}

The technique used in the Tesch approach (Creswell 1994: 154) was followed during the data analysis phase. The researcher got a sense of the whole by reading through all the transcripts. Similar topics were clustered together and merged into columns. Topics were abbreviated as codes, and descriptive wording given to each topic. These were turned into categories. The data material for each category was assembled in one place and analyzed.

\section{Ethical implications}

In this study, the participants were diverse, coming form different ethnic backgrounds. To prevent emotional harm to any of the participants, the different value systems, community standards, and professional levels, of the two communities (the researcher and the street children) had to be taken into consideration.

\section{Harm and risk}

The local police and rehabilitated street children pledged to safeguard the participants.

\section{Informed consent}

To ensure that there was not a relationship of mistrust amongst the participants (Miles\& Huberman 1994: 291, Polit $\&$ Hungler 1997: 133), informed consent was received verbally from all the participants involved. From the outset, the researcher was very clear about defining the purpose of the study. Ethical approval to conduct the study was granted by the Ethics Committee, Faculty of Health Sciences, University of Pretoria.

\section{Honesty and trust}

Violation of self-determination is another aspect that was taken into consideration, in view of the approach used during this study. An atmosphere of honesty and trust was established from the outset, with no hidden agendas.

\section{Confidentiality and anonymity}

The participant's anonymity was ensured; the names of the participants were not used. The data and participants' names were kept separate. It was impossible to link data to a specific participant. The tapes were destroyed after the completion of the research project.

\section{Privacy}

The rights, interests and wishes of participants were respected at all times. Also, the participants' privacy was respected, to allow them to think and share information/ experiences, without any interference. The researcher collected only information relevant to the study.

\section{Termination}

The right to withdraw from the study was explained to the participants.

\section{Trustworthiness of the study Credibility}

The credibility of a study is ensured if the findings are a true reflection of reality (Holloway \& Wheeler 1996: 165). In this study, the following were used to ensure credibility:

\section{Member checking}

In this study, the researcher referred themes, which emerged from the data, to the participants. The participants were asked if the interpretations of the researcher were accurate and if the researcher has not omitted any aspects of their experiences. This was done to verify the meaning that was extracted from the data. This technique was used throughout the data collection process, to confirm the truth value or accuracy of the interpretation. The final structure was developed after the discussion with the participants (Holloway \& Wheeler 1996: 166). Trustworthiness of findings in qualitative research is demonstrated when participants recognize the reported research findings as accurately representing their own experience (Krefting 1991: 217).

\section{Prolonged engagement}

Before the actual data gathering started, the researcher had already been involved with the street children, for the previous 18 months, as a voluntary worker. The researcher allowed enough time to establish rapport for the participants to respond, reflect on themselves, and verbalize their experiences, during the focus groups. The researcher spent time on verbatim transcriptions and data analysis, which gave more insight into data. A lengthened period of time was spent with the participants. This provided the researcher the opportunity to control the perspectives of the participants. It also allowed the participants to become used to the researcher.

\section{Reflexivity}

Reflexivity refers to the assessment of the influence of the researcher's own background, perceptions and interests on the qualitative process. The researcher decided not to facilitate the focus groups herself, because her experience in the field of street children could possibly influence th 3 participants. The researcher acted as field worker. This made it possible to remain up to date with everything that happened during the focus groups. Field notes were written following each contact with the focus group, with the purpose of auditing. Field notes are similar to notes kept in a diary, and it reflects the researcher's thoughts, feelings and ideas, that originate as a result of contact with the participants (Krefting 1991: 218)

\section{Transferability}

In this study, an in-depth description of the design, methodology and literature review was used to enhance clarity. This allows accurate replication or transferability.

\section{Dependability}

Member control was used regarding all the data. The participants examined the interpreted data to confirm that it was a version of their story. The participants were invited to comment on the reconstruction of the final interpretation of the data. Peer group investigation occurred when the researcher discussed the research process and findings, with impartial colleagues, who are experienced in qualitative research. This had been done continuously, in the form of an informal discussion with various lecturers, who critically evaluated the study and challenged the researcher on how certain decisions were made.

\section{Triangulation}

Multiple triangulation was used in this study, consisting of the triangulation of data, methods and investigations. The 
focus group data was combined by means of interviews. Data was also confirmed by conducting an extensive literature study. If, according to Carey (1994: 224), the various methods produce the same data, the method triangulation increases the trustworthiness of the study. Investigator triangulation was used in the sense that an independent investigator facilitated the focus groups, and the researcher collected the data through interviews. "Investigator triangulation is considered to have occurred when each investigator has a prominent role in the study, the expertise of each investigator is different, and the expertise of each investigator is evident in the study" (Carey 1994: 225).

\section{Confirmability}

Confirmability of the study means that the researcher clearly and logically describes the strategies used in the study, so that others can follow the way of analysis and arrive at similar results and conclusions. This can ensure the study's trustworthiness (Krefting 1991: 222). Confirmation strategies include triangulation techniques and confirmation audits, as previously discussed.

\section{Data interpretation}

\section{Themes and categories}

\section{Wellness}

\begin{tabular}{|c|c|}
\hline $\begin{array}{l}\text { Categories and } \\
\text { themes }\end{array}$ & Direct quotations \\
\hline $\begin{array}{l}\text { Wellness: } \\
\text { A healthy heart }\end{array}$ & $\begin{array}{l}\text { "If you are healthy you are fat, I mean } \\
\text { like a bodybuilder." } \\
\text { "Ja, and if you are a woman you must } \\
\text { be slender." } \\
\text { "It would say the guy's heart is sick } \\
\text { if he is sad, his face will tell you his } \\
\text { heart is sick." }\end{array}$ \\
\hline $\begin{array}{l}\text { Work and earning } \\
\text { some money }\end{array}$ & $\begin{array}{l}\text { "If his heart could talk, he will tell you } \\
\text { he (heart) is sick because he has no } \\
\text { place to stay or sleep, nothing to eat } \\
\text { and no parents." } \\
\text { "If you have a job you will have } \\
\text { money and a good home." } \\
\text { "People see a nice home and they } \\
\text { think you are a healthy person, no } \\
\text { problems." }\end{array}$ \\
\hline
\end{tabular}

In general, the street children mentioned that, to be a healthy person is not to have a broken body. A healthy person is also living, eating and working. Some of the children felt that, if the body must be healthy, the heart must be healthy too. In general the street children mentioned that a healthy person must also have a job and earn some money.

\section{Shelters}

The majority of street children view shelters as safe and

\section{The influence of the environment on the street children's wellness}

\begin{tabular}{|c|c|}
\hline $\begin{array}{l}\text { Categories and } \\
\text { themes }\end{array}$ & Direct quotations \\
\hline $\begin{array}{l}\text { The influence of the } \\
\text { environment on the } \\
\text { street children's } \\
\text { wellness: }\end{array}$ & \\
\hline Shelters & $\begin{array}{l}\text { "The rules are hard to follow, no } \\
\text { smoking, glue sniffing or drink- } \\
\text { ing." } \\
\text { "They treat you like home a lit- } \\
\text { tle here, but they do not let you } \\
\text { go outside much--you start feel- } \\
\text { ing cooped up and gotta let en- } \\
\text { ergy out." }\end{array}$ \\
\hline \multirow[t]{2}{*}{ Streets } & $\begin{array}{l}\text { "You only get a place to sleep } \\
\text { and some food, expired food } \\
\text { other people do not want to eat." } \\
\text { "Thee people at the shelter do } \\
\text { not take out money, but they } \\
\text { expect us to stop the habits, } \\
\text { nobody helps us. We must just } \\
\text { do it?" }\end{array}$ \\
\hline & $\begin{array}{l}\text { "There are unsafe areas where } \\
\text { men hang out and pick on you } \\
\text { and ask you for sex." } \\
\text { "Just kids who do not have a } \\
\text { place right now." }\end{array}$ \\
\hline
\end{tabular}

adequate living situations, although they often complain about shelter rules.

Towards the end of their shelter stay, many street children speak of anxiety over leaving the shelter. Living in a shelter for a while, "you get used to the rules", and when you leave you "gotta meet new people and start in a new environment."

\section{Streets}

The street children identify outdoor recreation sites, such as parks and soccer fields, as common hangouts. The description of street hangouts was further investigated by asking the street children why certain areas are considered unsafe. The majority of responses reflected the fact that "you can get shot just standing around and minding your business." Two street children also responded that some areas were unsafe because the police could pick them up "just for being there."

All the street children identified abandoned buildings as unsafe, because of drug dealing and drug use that can occur in these settings. In a three-block radius from the Koffie Huis, 14 boys, aged between 9-16, sleep on porches 
in good weather and mostly in cracked houses or abandoned buildings the rest of the time. Most are from families whose parents were 'strung out on drugs'. Different community members, mostly shop owners, sometimes feed them, "usually food that has been expired."

The community refers to the street children as 'hangin' (as opposed to hanging out). The street children, who took part in the focus groups, refer to themselves as children without homes - as one of the participants reported 'the street can't have children'.

The focus group discussions, led to the following statements about why the children have left their homes, and have come to the streets of Sunnyside:

\section{Paths of homelessness affecting street children's wellness}

\begin{tabular}{|l|l|}
\hline $\begin{array}{l}\text { Categories and } \\
\text { themes }\end{array}$ & Direct quotations \\
\hline $\begin{array}{l}\text { Paths of homeless- } \\
\text { ness affecting } \\
\text { street children's } \\
\text { wellness }\end{array}$ & $\begin{array}{l}\text { "Mother is an 'off and on } \\
\text { drinker'." } \\
\text { "Threw me out of the house when } \\
\text { she found out I did not attend } \\
\text { school regularly." } \\
\text { "My grandmother suspects that I } \\
\text { am stealing cell phones." } \\
\text { "I had a stepfather, a night watch- } \\
\text { man, and I did not like him." } \\
\text { "Those people (foster parents) } \\
\text { also drank a lot and I didn't like } \\
\text { it." }\end{array}$ \\
\hline
\end{tabular}

- $\quad$ substance abuse by parents or family,

- repeatedly runaway from home,

- death of one or both parents,

- school expulsions.

\section{Wellness seeking behaviors}

The supportive framework (as in a family), extends from illness, economic requirements and shelter, to the realm of enjoyment. Support is offered in cases of illness. A group of children negotiated with the cinema manager, for the use of a room in the building, so that an ailing street child could lie and recover, while the rest of the group tended to him. Some members of the group helped the manager with odd jobs, to pay for the use of the room.

In another incident, a car knocked down a street child while he was 'immune' from danger (intoxicated from sniffing paint thinners and feeling very confident). His friends carried him several meters to the nearest all-night café. The owner then summoned an ambulance for him. "If he was not your friend, we would kave left him in the street." In Sunnyside, a relatively small area, most street children know each other, at least by sight. Individuals are not necessarily bound to any single group but can, and do change their friendship
Wellness seeking behaviors and access to care

\begin{tabular}{|c|c|}
\hline Categories and themes & Direct quotations \\
\hline $\begin{array}{l}\text { Wellness seeking be- } \\
\text { haviours: }\end{array}$ & \\
\hline $\begin{array}{l}\text { Wellness seeking be- } \\
\text { haviour }\end{array}$ & $\begin{array}{l}\text { Most of the street children said } \\
\text { the first person they will tell } \\
\text { that they are sick is "my } \\
\text { mother." } \\
\text { Facilitator: "but you are home- } \\
\text { less, you have no mother on } \\
\text { the street." } \\
\text { If they are not at home they } \\
\text { will tell "the one that is look- } \\
\text { ing after me." } \\
\text { The street children were posi- } \\
\text { tive that the oldest fellow in } \\
\text { the group looks after the rest, } \\
\text { and they will go to him for } \\
\text { help. } \\
\text { "If we see you (the researcher), } \\
\text { in the street we will go to you } \\
\text { for help, we trust you." } \\
\text { Many street children practice } \\
\text { self-medication: "If I have a } \\
\text { runny tummy I drink castor } \\
\text { oil." } \\
\text { They also delay seeking medi- } \\
\text { cal advice: "We only go to the } \\
\text { hospital if it is very serious, or } \\
\text { if we are bleeding heavily." }\end{array}$ \\
\hline Access to care & $\begin{array}{l}\text { "They (the staff), treat you } \\
\text { with respect and will not give } \\
\text { you your tests results without } \\
\text { asking, "where is your mom'." } \\
\text { "They ask too many ques- } \\
\text { tions." }\end{array}$ \\
\hline
\end{tabular}

groups as frequently as they desire. While in a group, however, they will stand by their fellows/friends, as seen in the examples.

The street children identified the emergency room of the Pretoria Academic Hospital, located near Sunnyside, as a place they would go if they got hurt. The street children identified emergency rooms as convenient: "They are always open - you may have to wait forever, but eventually you will be seen." On further questioning, most of the street children stated that they would go to the emergency room if they got hurt or "really sick you know. Something that cannot wait, or if you did not see the pastor at the shelter."

On questioning what 'really sick' means: "Ja, like losing weight, sores on the face and skin, hey maybe sweating a lot." One street child stated that he must be "serious sick" 
before he goes to the hospital: "Ja, bad, really bad pain or bleeding, runny tummy - no hospital, just castor oil."

One participant stated that he is ill when his mind tells him: "my heart beat change and I don't feel like eating." He also stated that he has not been to hospital in the last two years: "I treat myself, lie down for a few days, or Panados from the pastor, Father Felix."

Three street children identified the primary health care clinics as places you go for "female stuff or if you thought you have STIs."

One street child responded that it was "just for adults and bums that are homeless."

Several responded that they do not consider themselves homeless, "at least not like them."

\section{Access to care}

In the interviews, several youths discussed problems with access to care, such as: "They hassle you about medical aid, money and stuff", and "They (street children), cannot make their own appointments; their parents have to go with them."

Street children have a fear of being labeled and rejected by health personnel. They also have difficulty navigating the large bureaucracies of health institutions. Confidentiality was cited as an issue: "They (street children), do not want their parents to know sometimes."

Specific comments of the street children reflected issues of access to care, including health staff judgementalism. Other problems with getting health care were, waiting times, payment, and confusion over the need for parental consent. "I never know when they are gonna make me bring my mom or when they gonna call the police or social worker and they will put me in a shelter or try to find my parents and send me back."

\section{Sources of advice}

The street children stated that they would first try to take

\section{Sources of advice and wellness education}

\begin{tabular}{|l|l|}
\hline $\begin{array}{l}\text { Categories and } \\
\text { themes }\end{array}$ & Direct quotations \\
\hline $\begin{array}{l}\text { Sources of advice and } \\
\text { wellness education: }\end{array}$ & $\begin{array}{l}\text { "I want to talk to someone not } \\
\text { too old - it is not age - it is } \\
\text { attitude, you know, 'old" is } \\
\text { when they do not want to lis- } \\
\text { ten, just want to preach at } \\
\text { you." }\end{array}$ \\
\hline Sources of advice \\
"Adliness education & $\begin{array}{l}\text { And tell us what is real." } \\
\text { and to listen to us }\end{array}$ \\
\hline
\end{tabular}

care of health problems themselves. Then they would ask friends for advice or they would ask their mothers, grandmothers or other trusted adult figures. "I would want an adult with experience and knows what they are talking about'.

There was also a discussion of what types of adult behavior and attitudes helped make it easier for youth, to seek advice. It was commonly reported that the street children are in regular contact with parents or other family members: "I won't be here for the second session, I'm going to visit my auntie." This contact occurred by telephone and by visits in the community, and was continued during the times spent living on the street.

It is clear that these family members are important sources of support and advice about health issues for street children, even for street children who experienced considerable neglect and abuse from the same families. One street child summarized this sentiment by saying, "I cannot live with her, but she is still my mom."

\section{Wellness education}

Several street children stated that personal testimonials are helpful: "You know, peoples' real life stories about having been on drugs and getting AIDS; it gets to you and makes you think." Street children agreed that role-play in peer groups, about common, difficult relationship issues, such as "talking to your friend about condoms and stuff," is useful and 'real'. One street child commented that, through this method, "you get to hear ideas about what you can say and maybe what you could do different next time."

\section{IIInesses perceived by street children}

The facilitator assisted street children in a discussion of what they perceive to be the main health problems and the major barriers to health care, of street children like themselves. The researcher and facilitator gave each street child

\section{Table 2 Common health problems of Sunnyside street children, based on free listing $(n=9)$}

\begin{tabular}{|l|l|}
\hline Health problems & Number \\
\hline HIV/AIDS & 9 \\
\hline Heart disease/sad heart & 8 \\
\hline Injuries/cuts & 8 \\
\hline STIs & 8 \\
\hline Drug use & 8 \\
\hline Depression & 7 \\
\hline Bad colds & 6 \\
\hline Cancer & 5 \\
\hline Mental problems & 4 \\
\hline Earinfection & 3 \\
\hline Bad teeth & 3 \\
\hline
\end{tabular}


Illness

\begin{tabular}{|l|l|}
\hline Categories and themes & Direct quotations \\
\hline Illness: & \\
\hline $\begin{array}{l}\text { Illness perceived by } \\
\text { street children }\end{array}$ & $\begin{array}{l}\text { A street child, who spent con- } \\
\text { siderable time on the streets, } \\
\text { spoke on the functional value } \\
\text { of drug use: "Sometimes it } \\
\text { gets so bad out there, drugs } \\
\text { get you through." } \\
\text { Smoking dagga, sniffing glue } \\
\text { and drinking 'blue train' (men- } \\
\text { tholated spirits), helps for the } \\
\text { pain, hunger and cold, if you } \\
\text { use it you do not feel any- } \\
\text { thing." } \\
\text { "We are always getting into } \\
\text { fights and getting cut up and } \\
\text { bruised." } \\
\text { The children state that 'de- } \\
\text { pression', is different from } \\
\text { "mental problems" Mental } \\
\text { problems are "more serious" } \\
\text { - it is like being really messed } \\
\text { up in the head from being } \\
\text { born that way." } \\
\text { In general the street children } \\
\text { sometimes felt very lonely, } \\
\text { "most of the nights." } \\
\text { "This heart needs to talk to a } \\
\text { person, he is very lonely - if I } \\
\text { see somebody I know we talk } \\
\text { and laugh, the happiness } \\
\text { comes back for a short while." } \\
\text { "People don't want to see us. } \\
\text { It is if we are a bad dream. } \\
\text { They just want us to go away. } \\
\text { They don't love us. We are } \\
\text { not even as good as animals. } \\
\text { They forget that children with- } \\
\text { out home are people too." }\end{array}$ \\
\hline
\end{tabular}

a pencil and paper and asked them to respond to the question: "What are the different kinds of health problems that street children like you have?" The following question was also asked: "Which of these health problems have you ever had?" The free listing activity resulted in 11 different health problems, as shown in Table 2.

Most responses were for specific illnesses such as AIDS and STIs, but also included less specific conditions, such as skin problems and bad teeth. The street children divided common health problems into ones that 'deal with sex', and ones that 'happen to your body'. They further differentiated sex-related health problems into ones that street children can catch from someone (e.g. STIs and HIV/AIDS), and ones that 'just happen' (teenage pregnancy).

They divided the health problems of "your body", into ones that "can kill you" (cancer), ones "not as serious" (bad colds) and ones "in the mind" (depression). The diseases that the street children were most afraid of getting were HIV/AIDS, followed by injuries/cuts, heart disease, STIs and depression.

The street children spoke of knowing at least one person who "has AIDS." One street child stated; "You see AIDS eating them up from the inside - it is scary." They reported having had health education at the Koffie Huis and on the streets, focusing on HIV/AIDS, and "how always to wear a condom - how easy it is to catch AIDS."

The children reported that they are afraid of "catching AIDS by eating out of the same pot - some of the children's hands have sores on and even bleeding." The street children also spoke freely of their knowledge, of and exposure to, street drugs, with many talking about close friends who "cannot shake it - once you get hooked on that stuff it is hard to get off"." Several reported that the main drugs of street children, like them, are glue, alcohol or benzene and marijuana/dagga, or, as they call it, GAGA.

Several street children talked about injuries as a health problem. A street child who had spent several weeks on the streets, during freezing July weather, living in cars to stay warm, reported that injuries were his main health-related problem while on the streets. He stated that he broke a car window with his fist: "I covered it up with my T-shirt but still got cut up." He said that he tried to wash the cuts, but "they got dirt in them and got infected."

A newcomer to the streets, who had been on the streets for only three weeks, 'pimped' on the rest of his group to the police, about a housebreaking incident. He was very severely beaten by the group, and ended up in hospital. According to the rest of the group, this hiding was simply part of teaching him the skills of the road - to protect his fellow street friends, above all other alliances.

Many of the street children spoke of the anxiety and loneliness that comes from "not having a home - you know, a place and people to love you." One street child stated that he sleeps during the day, and at night, he tries to stay awake. "If I go to sleep at night, it is dangerous, I am afraid of the older street children - they abuse us, and the vampire that bites you when you sleep - he is from the Satan."

Some street children are afraid that they will die in their sleep and that the police will come and take them away. "They will throw you in a big hole and no one will know that you are dead - the police do not tell your parents, or friends, you are dead - they are glad to get rid of us."

The street children stated how they missed their mothers, how a friend was wetting his pants in his sleep, and of not being able to handle a single more night. They grieve for the loss of their family, and for the loss of their childhood a cherished bicycle, lost brothers and sisters. 
Figure 1 Health needs of street children

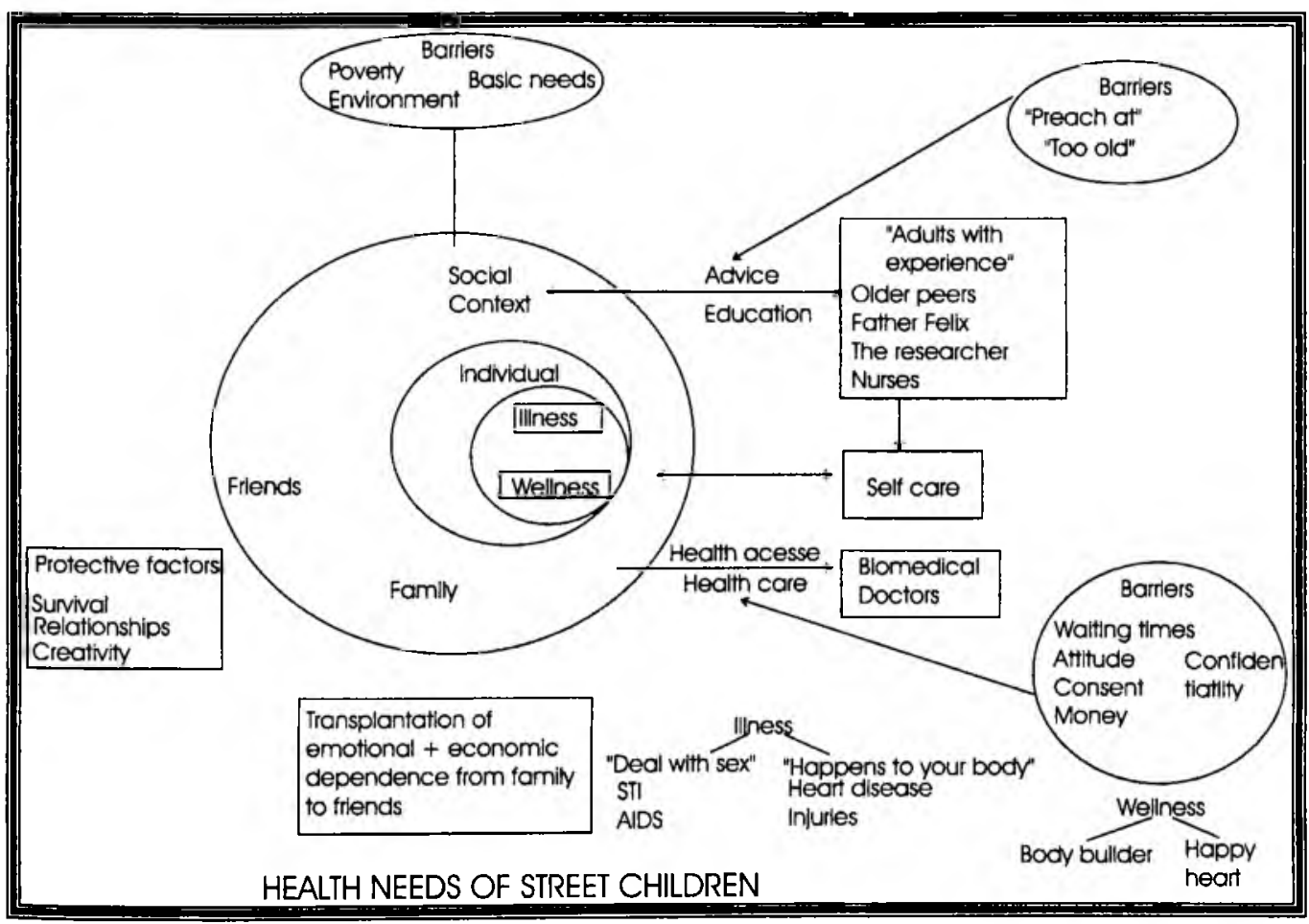

from the qualitative data.

- Street children view wellness, wellness education, and access to health care, as part of a larger context that includes peers, friends and family.

- A variety of forms of violence are also a part of the street children's social context.

- Street children see illness as being within the individual and caused either by individual behaviors, or by things outside a person's control.

- They speak of wellness as being "something you gotta take care of," that comes mainly from individual self-care behaviors and not from seeking medical care "when you need it."

- The street children place high value on peer interactions (shown within social context), and on guidance from adults with experience.

- $\quad$ The street children seek advice and care from their friends, "cause they know what it is like," but also from family.

- Many of the street children continue to have some contact with parents, grandparents and other family members, even during their experience with homelessness.

- The street children get angry at rules and boundaries set by adults, but they also seek advice from adults who "do not preach."

- They view doctors and the health care system in a narrow biomedical context: "They give you pills, injections or they try to fix something."

Wellness education is outside the medical care system, linked with various figures such as older peers, the pastor, Father Felix, and voluntary workers from the Koffie Huis, with whom the street children interact on a daily basis.

\section{Recommendations}

\section{Services}

Efforts should be made to keep street children in their own communities, perhaps through the addition of supervised group homes, as an alternative to foster care.

As mentioned previously, the street children accept health education, if it provides examples of realistic peer and wellknown sport heroes' interactions, within the context of health behaviors, and if it provides positive guidance. The 
street children clearly want adult advice and guidance on health related issues, as long as it is not judgmental or irrelevant to their current situation.

Community programmes should be designed for street children, by providing practical information on how to talk to street children about difficult subjects such as sex and drugs, and by providing information on accessing local health social services for children in need.

In conjunction with the Medical Faculty of the University of Pretoria and the Pretoria Academic Hospital, students and tutors can run an outreach clinic at the Koffie Huis. All children that are registered at the Koffie Huis, can get free consultations from the students, accompanied by their tutors. A child with a severe health problem can be referred to the hospital for treatment.

It is important to note that street children, who are homeless and from less than ideal family situations, remain in contact with, and continue to seek advice from parents and other family members. These family connections should be recognized and supported whenever possible.

Local health departments should increase access to community-based adolescent health clinics, such as school and mall-based teen clinics.

The general concern and confusion, regarding the need for parental consent for care, indicates that health facilities should clarify their policies, about the provision of health care, to unaccompanied street children, and should clearly post these policies in waiting rooms.

\section{Education}

The street children showed considerable insight and creativity during focus group discussions and activities about the perception of health and health needs. The children were interested in being included in the planning and implementation of health education initiatives. Their intellectual and problem solving capacities are far above what would be predicted, when considering their backgrounds.

The street children were generally energetic in art and music, and these media could be used for health education.

It is important that the curriculum of nursing students must include the health promotion of vulnerable groups, such as street children. As seen in the literature, and the research that has been done, there is an increasing number of street children in South Africa. With the mortality of people, because of HIV/AIDS, these numbers can increase tremendously.

\section{Research}

Follow-up research is needed on how best to identify these street children, and assist them, with appropriate access to health and social services. Such interventions should be done in conjunction with the existing community support networks, for these children.
Instead of focusing on the pathology of inner city street children in particular, it would be beneficial for health researchers, to begin examining the street child's strengths, and also, what is working with this population.

\section{Limitations}

It is important to note that the street children included in this study were all black boys between the ages of 9 and 13 .

However, important gender and ethnic variations in responses may have been missed in this research. In addition, probable differences in responses, between different age categories, were not captured in this research.

While all the participants were informed of the research, one child seemed to view the research as part of the Koffie Huis is general information sessions.

\section{Conclusion}

The findings of this research revealed two major themes:

- Wellness

- Illness

The findings of this research revealed five categories:

- Influences the environment has on street children's wellness

- Paths of homelessness of street children of Sunnyside, that play a leading role in their wellness

- Wellness seeking behaviors, of the street children of Sunnyside, and the access to care they make use of

- $\quad$ Sources of advice and wellness education the street children of Sunnyside make use of

- Illnesses perceived by the street children of Sunnyside

The data present the self-perceived health problems and access to health care of the street children, within a sociocultural context. The most commonly identified health problems (as identified by street children), are HIV/AIDS, heart diseases/sad heart, injuries and cuts, STIs, drug use and bad colds. These correlate well with findings from quantitative health assessments of street children in Baltimore (Ensign \& Santelli 1977: 817). The street children acknowledge the role of individual risk taking behaviors in the development of many of these common health problems.

Issues of confidentiality were important for the street children, especially sexually related health problems. It appears that the street children avoid non-urgent, emergency care visits and instead practice self-medication, or seek primary health care, if it is 'child friendly'.

\section{References}

CAREY, MA 1994: The group effect in focus groups: Planning, implementing and interpreting focus group research. (In JM Morse (Ed.), Critical issues in qualitative research 
methods). Thousand Oaks, CA: Sage Publishers.

COCKBURN, A 1991: From concern to concrete action: the story of The Homestead. (In B Gannon (Ed.), Today's child; tomorrow's adult). Cape Town: National Association of Child Care Workers.

CRESWELL, JW 1994: Research design. Qualitative and quantitative approaches. London: Sage Publishers.

DE VOS, AS 1998: Research at Grass Roots - A primer for the caring Professions. 1st ed. Johannesburg: Van Schaik Publishers.

DONALD, D \& SWART-KRUGER, J 1994: The South African street child: developmental implications. South African Psychology. 24(4): 169-174.

ENSIGN, BJ \& SANTELLI, J 1977: Shelter-based homeless youth: Health and access to care. Archives of Pediatrics and Adolescent Medicine. 151(8): 817-823.

GEBERS, P 1990: Health of street children in Cape Town. The Child Care Worker, 8: 11-14.

HOLLOWAY, I \& WHEELER,S 1996: Qualitative Research for nurses. United States of America: Blackwell Science.

JENKINS, D \& EMMET, S 1997: The ethical dilemma of health education. Professional Nurse. 12(6): 426-428.

KREFTING, L 1991: Rigor in qualitative research; the assessment of trustworthiness. The American Journal of Occupational Therapy. 45 (3): 214-222.

MLES, MB \& HUBERMAN, AM 1994: Qualitative Data Analysis. An Expanded Sourcebook. 2nd ed. California: Sage Publications.

POLIT, DF \& HUNGLER, BP 1997: Essentials of Nursing Research. Methods, Appraisal and Utilization, 4th ed. Philadelphia: Lippincott.

RICHTER, LD 1990: South African 'street children': comparison with Anglo American runaways. (In N. Bleichrodt and P. Drenth (Eds.), Contemporary issues in cross-cultural psychology). Amsterdam: Swets and Zeitliger, p. 96-109.

RICHTER, LM 1991: Street children in South Africa: street children in rich and poor countries. The Child Care Worker. 9:5-7.

SWART, J 1990: Street children: their health and welfare. Journal of Comprehensive Health in South Africa. 1: 5-12.

VAN RENSBURG, HJ 1994: Primary Health Care in Disadvantaged Communities in South Africa. Medicine and Law. 13(1): 133-139. 